\title{
Religious education and nation-building in Nigeria
}

\author{
Ajah, Miracle ${ }^{1}$ \\ Stellenbosch University \\ majah@noun.edu.ng
}

\begin{abstract}
After the Nigerian Civil War in 1970, the federal government took over schools founded by religious groups because education was thought to be a huge government venture and no longer a private enterprise. Prior to this time, Nigerian leaders benefitted from the free education offered by missionaries, which became the bedrock for Nigerian nationalism and independence. Most people argue that the sudden takeover of the schools by the government brought about the collapse of education that was hitherto reputed for high standards in learning and morality. Hence, the call for return of mission schools by pressure groups became rife. Conversely, in the wake of the return of mission schools by some states in the federation, stakeholders have expressed divergent views, citing denominational sentiments, tribal prejudices and unhealthy rivalry among citizens as problems that could militate against national integration and development. This article aims at examining the divergent views in the light of the role of religious education (RE) in nation building and integration.
\end{abstract}

\section{Keywords}

Religious education, Mission schools, Nigeria, nation-building, nation-integration

\section{Introduction}

This article addresses the topic: "Religious education and nation-building in Nigeria." Some argue that the federal government of Nigeria took over mission schools after the Nigerian Civil War in 1970, in order to combat the problem of tribalism (Fagbunmi 2005:1-7; Efobi 2011:6). On the other hand, education was regarded as a huge government venture and no longer a private enterprise, hence the Government intervention (Imam 2012:187189). Since nineteenth century, mission schools, which were founded by

1 National Open University of Nigeria, Lagos 
foreign missionaries promoted Western education that was offered free or highly subsidized in most cases. Many of today's Nigerian leaders benefitted from the free education offered by the missionaries, which became the bedrock for Nigerian nationalism and independence. Most people argue that the sudden takeover of the schools by the government brought about the collapse of education in schools that were hitherto reputed for high standards; morality and character building also collapsed (The Guardian 2013:15).Given the central importance of formal education, it soon became "the largest social programme of all governments of the federation," absorbing as much as 40 percent of the budgets of some state governments. Thus, by $1984-85$ more than 13 million pupils attended almost 35,000 public primary schools. Universal primary education became official policy for the federation in the 1970s. The goal has not been reached despite pressure throughout the 1980s to do so (OnlineNigeria 2013:12).

This period witnessed both an explosion in population of people scrambling for education, with its attendant paucity of infrastructure. Economic hardship among teaching staff produced increased engagement in non-academic commercial activities, in an attempt to alleviate their sufferings. Added to these difficulties were such factors as the lack of books and materials, no incentive for research and writing, the use of outdated notes and materials, and the deficiency of replacement laboratory equipment. Other problems included incessant strike actions by teachers and mass exodus of lecturers to greener pastures abroad. By 1990 the crisis in education was such that it was predicted that by the end of the decade, there would be insufficient personnel to run essential services of the country (Imam 2012:189). The failure of government to adequately fund education and improve the condition of the schools created burden. So there was a mounting pressure by interest groups on the States to return the schools to their owners. Apparently, the state governments, which felt over-burdened, found the demand for handover of schools a ready escape route from the statutory responsibility of catering for the schools. Thus, by handing over hundreds of schools to their owners, they had lesser burden to carry on the education front. They thought this would be a solution but it created new problems.

Establishment of private universities received legal backing in 1999. By 31 December 2010, there were 41 private universities mostly owned by 
religious organizations, both Christian and Moslem. One of them was owned by an ethnic organization, while five belonged to private individuals (Okafor 2011:389). The high fees charged by private universities actually made it a private institution for the rich only, thereby excluding the poor and the less privileged; pointing to funding problems as the reason for that. Conversely, in the wake of the return of mission schools by some states in the federation, stakeholders have expressed divergent views, citing denominational sentiments, tribal prejudices and unhealthy rivalry among citizens, as problems that could militate against national integration and development.

So this article aims at appraising the divergent views in the light of the role of religious education (RE) in nation building and integration by tracing:

- The history of different educational traditions in Nigeria.

- Reasons for government takeover of mission schools.

- Divergent views on the return of mission schools by government.

- An Appraisal of the Divergent Views

- A way forward for religious education in Nigeria.

The term "Religious Education" has been variously defined. On one hand, it is seen as the teaching of a particular religion and its varied aspects its beliefs, doctrines, rituals, customs, rites, and personal roles. Religious Education, according to Encyclopaedia of Education Research (1979:1123), conceived religious education as those enterprises of religion to induct each new generation into the attitudes, beliefs and practices of particular religion, therefore perpetuating the religion and at the same time providing for the individual unifying centre for his life. It entails that religious education is the process by which any religious body indoctrinate and trains its members especially the young ones in its beliefs and practices. On the other hand, Religious education is viewed from the different theoretical and practical dimensions of religiosity, a model posited by Ulrich Hermel (Adam, Rothgangel \& Lachmann 2014:15-20). According this model, Religious education was described in terms of:

- Religious sensitivity: the affective dimension of religiosity is fundamental. This is similar to Schleiermacher's definition of religion as "feeling of absolute dependence". Furthermore, it covers the field of religious perception. 
- Religious content: the cognitive dimension of religiosity is, for example, documented by the creed, or in the basic knowledge of biblical texts and church historical developments.

- Religious behaviour: the pragmatic dimension of religiosity is, for instance, displayed in rites and prayers, as well as in community and humanitarian activities.

- Religious communication: the basis for this communicative dimension is a religious vocabulary and a religious grammar, to be able to, for example, articulate one's religious feelings and attitudes. The religious dialogue with different denominations, religions and world views is also part of this.

- Religiously motivated lifestyle: this is a special dimension of religiosity which encompasses all other dimensions. A differentiated evolution of the other dimensions by no means indicates that a person is motivated and willing to shape and organize their life accordingly.

While some people argue that differences in religious and non-religious belief vis-a-vis government-sponsored religious education can be a source of conflict; others argue that religious beliefs have historically socialized people's behaviour and morality, that teaching religion in school is important to encourage children to be responsible, spiritually sound adults. Education is regarded by Nigerians as the main instrument for social, political and economic development of the nation. Thus the strength, security and wellbeing of Nigeria rests squarely on the quality of education provided for the citizens. It will continue to be a great asset to many as well as a steady source of manpower supply for the national economy.

Religion is a veritable tool for teaching and inculcating moral values. Orebanjo was right when he argued that moral values can be accomplished only with the teaching of religions, either formally, informally or nonformally; which is why religious education is part and parcel of all religious practices (Orebanjo 1974:434). The exclusion of religion from education would place a big question mark on how good morals could be inculcated in the society. Also UA Ajidagba opines that Nigeria as a country is in dire need of moral regeneration and religious rebirth, hence, the successive Nigerian governments, through various educational policies, have recognised the importance of religious education (Ajidagba 1996:1). 
Our concern in this article is not to discuss the different aspects of religious education, but to present the divergent views of individuals and groups on the Nigerian Government takeover and return of mission schools from 1970 to the present. Furthermore, the article focuses on the contributions of religious education in national development and integration in Nigeria. So the next section discusses the history of different educational traditions that have operated in Nigeria with a brief highlight of their contributions.

\section{History of different educational traditions in Nigeria}

Three different educational traditions have operated in Nigeria namely, indigenous, Islamic and Western. Indigenous education was the earliest type of education, which was offered in the pre-literate era, within the community, by community members who possessed specialized skills or abilities in various fields of human endeavour. Here, boys were mentored by their fathers, or other masters in learning various vocations and etiquette like farming, trading, craftwork, fishing, cattle rearing, wine tapping, traditional medicine and black-smiting, etc. While girls were expected to stay back at home to learn domestic and other chores such as cooking, sweeping, weeding the farmlands, hair weaving, decorations of the body, dye production; and the like from their mothers (Mkpa 2013:14). This educational tradition is sometimes referred to as precolonial or informal or tribal or community-based education in Africa. There were no schools, professional teachers and absence of students/pupils with uniforms, regimentation and permanent teachers as we have it today in Western education. There were centres for initiation and adult members of society served as teachers (Esu and Junaid 2012:1-3). Thus, traditional education, which was nurtured by traditional religions was the process by which every society attempted to preserve and upgrade the accumulated knowledge, skills and attitudes in its cultural setting and heritage to foster continuously the wellbeing of mankind (Esu and Junaid 2012:1-3).

The second type of educational tradition, Islamic learning had been established in Nigeria before the arrival of the Western type of education in the $19^{\text {th }}$ Century (Fafunwa 1974:53). In the early $14^{\text {th }}$ Century, Islam was brought into Hausa land by traders and scholars who came from Wangarawa to Kano in the reign of Ali Yaji (1349 - 1385). Before long, most of what later became the Northern Nigeria was islamised. Islamic education 
brought along with it Arabic learning, since Arabic is the language of the Quran and was therefore perceived as having great spiritual value. Arabic and Islam were taught simultaneously in primary schools. As a result of the political and social influence which Islam and Quranic learning conferred on those who possessed it, many rulers employed Islamic scholars as administrators (Mkpa 2013:1-4). The efforts of Uthman Dan Fodio helped to revive, spread and consolidate Islamic studies and extend access to education also to women. Islamic studies also penetrated the Western parts of Nigeria following this time. Support for Islamic education came from some Northern Nigerian leaders, especially Abdullahi Bayero (Emir of Kano), who, on his return from Mecca in 1934, introduced new ideas by building a Law School for training teachers of Islamic subjects and Arabic as well as English and Arithmetic (Mkpa 2013:1-4). Islamic education was more or less informal in nature under the tutelage of mallams or ulama, scholars who specialized in religious learning and teaching. By 1914, it was estimated that about 25000 Quranic schools were already in existence all over Northern Nigeria.

Western-style education was the third educational tradition that came to Nigeria championed by the Christian missionaries in the midnineteenth century. The development of this western type of education in Nigeria preceded the political unity of the nation in 1914 and subsequent independence in 1960. Wesleyan Methodist missionaries arrived in 1842, establishing a mission and a school, and in 1878, established first boys' school at Lagos and a girls' school by 1895 . The Church Missionary Society (CMS) established schools at Abeokuta, Badagry, Lagos and Ibadan from 1846-1949. The Holy Ghost Fathers (The Catholic Mission) open schools at Onitsha on the east of the Niger and convent schools at Abeokuta in 1886-1892. The United Free Church of Scotland (CSM - Presbyterian) founded the famous Hope Waddell Training Institute at Calabar in 1895 in the south east. They also had an extensive educational system that covered most of the middle and lower Cross River valley in the 1900s. The Presbyterians were consistent in believing that "concerns about equality of opportunity and about the rights of individuals, not least the rights of the child, are fully consistent with the ideals that are at the heart of Christianity" (Taylor 1996: 236). In 1904 the Sudan United Mission (SUM) operated along Benue River in the north, the longest tributary of the Niger. 
They focused on evangelism, using education and medicine as handmaids of the gospel. The different Christian missions used school as an organ of religious instruction, character formation, skill acquisition and initiation into the three basic elements of reading, writing and arithmetic. Among other crucial roles of the missionary enterprise were the establishment of mission hospitals and leprosy settlements; agriculture and farm settlements and providing worthwhile training and jobs for Africans in Nigeria. The missionary team included white missionaries, a medical man, an ordained educationalist and a horticulturalist (African Missions 2010:15).

Some have commented that the rapid expansion of education, particularly in southern Nigeria, was actually the accidental outcome of missionary rivalry between Catholic and Protestant Missionaries rather than the result of an altruistic policy to provide expanded educational opportunities for the Nigerian populace (Bassey 1997:47).

\section{Reasons for government takeover of mission schools}

Some of the reasons why the Nigeria federal government took over and nationalised all schools that were originally owned by the missions in 1970 are highlighted here. Earlier, in 1942, 97 per cent of Nigerian students were enrolled in Christian mission schools and up through the mid-1960's mission schools continued to educate the majority of children in the majority Christian Igbo (Southeast) and Yoruba (Southwest) dominated sections of the country. A desire to foster a common Nigerian identity following independence prompted the first wave of school nationalizations. The tempo increased rapidly however, following the Biafra Civil War (19671970) when state governments began nationalizing church owned schools and hospitals in a move to combat tribalism (Efobi 2011:6). Also, education was regarded as a huge government venture and no longer a private enterprise (Imam 2012: 187-189).

When the military came to power in January 1966, former regions were divided into states, and placed education on a residual list. The implication of which was each state enacted its educational laws according to its educational demands. As a means of fostering national unity, the federal Government established unity secondary schools called Federal Government Colleges, one in each state in which youths all over the nation 
vigorously competed for admission through a nationally administered common entrance examination (Abdullahi 2012:4).

In 1969 the National Curriculum Conference was convened which reviewed the educational system and its goals, and identified new national goals for Nigeria which would determine the future and direction of education in the country. The conference was the first national attempt to change the colonial orientation of the Nigerian educational system and promote national consciousness and self-reliance through the education process (Imam 2012:187-190). In order to consolidate on the gains of the curriculum conference, in 1973, the Federal Government instituted a seminar of distinguished experts to deliberate on a truly Nigerian national educational policy. This body also included a wide range of interests including the representatives of Muslim and Christian organizations in Nigeria. The report of the outcomes of the Seminar, which after due consideration by the States of the Federation and other interest groups was presented as the draft National Policy on Education (FRN 1981:17).

In 1970, the Federal Government took over mission schools as education was regarded as a huge government venture and no longer a private enterprise. Part of the reasons for the take-over was 'to provide stability, satisfy people's basic educational and national needs, combat sectionalism, religious conflict and disloyalty to the cause of a united Nigeria' (Fagbunmi 2005:1-7; cf. Imam 2012:187-190). By 1976, when the states of the Federation were increased to nineteen, each state promulgated an edict for the regulation of education, and its provision and management. Each state also amended the Federal education law when necessary, which resulted in all the states' edicts having common features, such as state take-over of schools from individuals and voluntary agencies, using similar curriculum and the establishment of school management boards as well as a unified teaching service (Fagbunmi, 2005:1-7).

The issue of school takeover actually started with East Central State, which was the worst affected from the Nigeria civil war. It began in 1970 with the administration of Mr. Ukpabi Asika (a civilian administrator appointed by the military government). Commentators still argue whether or not government succeeded in their mandate to carry out the three Rs, namely: reconstruction, rehabilitation and reconciliation of eastern Nigeria (Obibuaku 2005:1-3). 
The takeover of school by the government was not essentially a bad idea because of the initial successes registered. But the failure of government to adequately fund education and improve the condition of the schools created burden, including the failure of moral standard and discipline. New private schools were opened by individuals and religious groups, and they were no law working against it, and somehow introducing a complexity in the school system in Nigeria. Interest groups mounted pressures on the States to return schools to their former owners.

\section{Divergent views on the return of mission schools by government}

The first state to return mission schools was Lagos State in 2001. The state did this with the hope of seeing quality of education improve. Some of the states which returned schools to their original owners were Imo, Ogun, and Plateau, Anambra, and Abia. It was reported that the southern state of Anambra returned 1,040 primary schools to their original church owners, while neighbouring Delta handed over 40 schools. Some of these schools were returned without the repelling or amending of the laws that instituted the takeover of schools by government. For example, the administration of Otunba Gbenga Daniel (Ogun State) returned 23 public secondary schools through a Memorandum of Understanding (MoU) between the state government and owners of the mission schools. Meanwhile, a Memorandum of Understanding (MoU) is not a law and cannot amend or repeal a valid law (Kalu 2011:5). In this light, the whole exercise was faulted, claiming that the current trend in the return of mission schools stands on a false foundation, which an ambitious regime could overturn any day.

Most government teachers have refused employment in the returned schools, protesting that church operators were too strict and profitoriented. The National Union of Teachers (NUT) faulted the decision of states government to return public schools to missionaries, threatening to go on strike if the decision was not reversed. The union described the decision by the governors as a violation of the Compulsory Free Universal Basic Education Act 2004, and a total disservice to the nation. They argued that in an era when most governments in the world are progressively moving towards mass education through public funding, the Nigerian states governments are all out at returning education to elitist project, 
undeserving for the children of the poor masses. This view believes that the recourse to handing over primary schools is an attempt at commercializing universal basic education, which is dangerous to national development. So the NUT opposed the decision of returning public schools to the missions on the premise that it would subject parents and teachers to the whims and caprices of the missionaries. This stand was supported by the Nigeria Labour Congress - NLC (Osuagwu 2012:8).

Many church families complain they cannot afford to enrol their children. One of the placards carried in a recent protest against the return of schools to missionaries in Abeokuta, Ogun State reads: "Missionaries are now Capitalists." According to them:

These schools are not for the poor; they are too elitist, even members who donated toward their establishments cannot send their children there. They should have told us they are running profit-oriented schools from the outset instead of using the word mission to raise money, get public support, and turn around to become unaffordable.

(Christianity Today 2012:1-2)

Another argument being canvassed against the return of mission schools is that it has produced a dangerous negative impact in the educational sector and has reduced enrolments drastically. For example, in Abeokuta South Local government, where six schools were said to have been handed over to the original owners by the government, the total school enrolment of these schools in 2008 was 12 663. But by 2010, after the hand-over, students' enrolment dropped drastically to 401 for the simple reason that school fees were high. Consequently, 12262 students could not get access to secondary education. In Ijebu Ode, enrolment dropped from 8729 in 2008 to 876 by 2010 (Kalu 2011:5).

On the other hand, different religious groups have countered the opinions of those who argue against the return of schools to their former owners. They argue that mission schools are better equipped than public schools, and their students outperform their public counterparts on tests. That if they would continue to offer quality education and remain at the cutting edge, then somebody must pay. Early mission schools were free or highly subsidized because they were funded by foreign missionary agencies (Christianity Today 2012:1-2). 
Cardinal Onaiyekan posited that the takeover of missionary schools by state governments was wrong in the first place as it did not help the sector, given the steady decline of standards and morality. That what the government should have done was to collaborate with the owners of such schools and assist in whatever way possible, and not an outright takeover. He said:

The missionaries should be allowed to run their schools, so that we can properly bring up our children in the right way possible. Until this is done, the schools will continue to yearn for a return to their original owners just as the standards in our education sector will continue to deteriorate. That is why it has become imperative for state governments to return the missionary schools to their rightful owners without further delay.

(Onaiyekan 2013:4)

Some state governors commented in favour of return of mission schools to their owners. Examples are Abia State governor, Theodore Orji, who handed over 19 schools, and said that other schools compulsorily acquired will be handed over to their owners in due course, adding that the exercise was not limited to secondary schools but would later be extended to the primary schools. He lamented that discipline, morality as well as the standard of education had fallen since the takeover of schools by government in the 1970's (Onyekwere 2012:11). Similarly, Governor Peter Obi of Anambra state said:

The collapse of education in the state is directly connected with the takeover of schools owned by the missionaries, churches and voluntary organisations in 1970. That singular exercise signalled the disappearance of morality and building of character from our school system. This can no longer be allowed.

(Uzodinma 2013:2)

Furthermore, Governor Peter Obi made good his promise by donating N733 million to Catholic and Anglican churches to run schools handed back to them (Uzodinma 2013:2). An editorial in ThisDay Newspaper, Lagos applauded the return of mission schools. It noted that it was "concerns about national cohesion" that prompted the "summary usurpation of proprietary rights over private schools by government" in the 1970s. However, "whatever goodwill" the government expected from seizing the schools 
was lost by its "failure to compensate the original owners of the schools, or treat them with respect during the take-over process." Nationalization also saw a "collapse of values of discipline and staff integrity" and a "precipitous decline of academic standards." ThisDay called "for the return of schools to their original owners" as a way to stem the collapse, but urged the government not to wash its hands off education, and called for a uniform system of school inspections to ensure quality education for all Nigerians (ThisDay 2012:3).

\section{An appraisal of the divergent views}

From the foregoing, it is obvious that proponents for the return of mission schools to their original owners were mainly religious groups and some state governors; while those who opposed the idea were mainly employees like teachers in the school system, and beneficiaries of public education, like parents of pupils and students. The divergent views were shaped by their different contexts or by the situations they found themselves.

Analysing the views, Onyekakeyah (2013:18) was right when he observed that some state governments decided to hand over the schools by compulsion rather than reason. Over the years, mounting pressure by interest groups on the states to return the schools to their owners led to this turn of events. Besides, the failure of government to adequately fund education and improve the condition of the schools created burden. Apparently, the state governments, which appeared over-burdened, found the demand for handover of schools a ready escape route from the statutory responsibility of catering for the schools. Thus, by handing over hundreds of schools to the churches, they have lesser burden to carry on the education front. They thought this would be a solution but it has created new problems.

It is a fact that the collapse of education in terms of standards and morality in Nigeria could be traceable to the Government takeover of mission schools; it is also a fact that bad governance and corruption contributed to the collapse of not only education, but every other institution or sector in the Nigerian experience, as we can see the collapse of Nigeria Telecommunication (NITEL), National Electric Power Authority (NEPA), which became Power Holding Company of Nigeria (PHCN). The Postal System and Railway System have not fared better. Even as an Oil Nation, 
Nigeria has little or nothing to show for it as one of the highest oil producers in the world. So, system collapse in Nigeria did not affect only education; it affected every aspect of Nigeria's parastatals.

It should be remarked that the mission schools today cannot be compared to what they were before in terms of funding and orientation. The European missionaries used the mission schools as an agent of conversion to Christianity, and they funded it from their home fronts, making education either free or highly subsidized. But the situation is different today because the western missionaries have gone back with their funds. The "Moratorium debate" is still fresh in our memory. John Gatu's controversial paper in 1971, "Missionaries go home!" has continued to provoke interest and concern among emerging African scholarship. His focus was on the question: "why are mainstream African Churches unable to assert themselves in ecumenical foray?" He traced the cause of this shortcoming to the domination of such Churches by missionary personnel and funds. He suggested therefore that the missionaries should withdraw themselves and their funds, so that African Churches could cultivate their own selfunderstanding without the tutelage of foreign missionaries and mission boards (Gatu 1971:11). A host of other African scholars have expressed their discomfort on the dependency syndrome of African Churches. E.M. Uka (1989:252) wondered why Africa was still so dependent on western churches and other agencies after over a century of missionary enterprise in Africa. His emphasis was on changed relationships, and not on cessation of relationships (Uka 1989:250). Furthermore, Ogbu U. Kalu (1975:15-16) posed a similar question, "Why are churches in Africa...still needing to climb on someone else's shoulders to watch the parade." $\mathrm{He}$ argued that Africa's problem is not genetic nor the product of a non-viable environment, but that of a victim of exploitation and political enslavement. The end products were Churches which could not stand on their feet, and a relationship which made aid the glutinous agent for maintenance of a dependent relationship (Kalu 1975:18).

In the light of the above, running a mission school today in Nigeria as it was done before, with the hope of getting aids from abroad would tantamount to a misnomer. This is why most of the mission schools are becoming very expensive in a bid to raise funds, thereby reducing enrolments drastically, and making the schools an elitist enterprise. Considering the effort of the 
government towards universal education where there is little or no fee, returning schools to institutions that charge exorbitant fees and thereby discouraging people from going to school is counter-productive. Why should children in church schools be paying exorbitant fees when their mates in government schools are paying nothing and at the same time receiving free books, uniforms and other materials under the Universal Free Education policy? The outrageous fees being charged by church-owned universities when federal and state universities are comparatively free, illustrates the imminent danger of return of schools to churches and private individuals if it is not properly thought through (Onyekakeyah 2013:1-3).

On the other hand, it was wrong for the government to have appropriated schools without due compensations, which some state governments are trying hard to atone for today. This atonement by state governments is belated, because it looks like they have found an escape route to shy away from their responsibilities, just because of a call from few pressures groups on the return of mission schools. Collaborating with the private bodies in education should have been the ideal thing, instead of an outright appropriation. In that process, Government should have streamlined its education policy to require religious bodies and private individual to operate within the framework of government schools. The adoption of Public Private Partnership (PPP) by the federal government is a good indicator that it can collaborate with religious groups and individuals in education (Ward \& Ariguzo, 2006:17).

\section{A way forward for religious education in Nigeria}

The role of religious education in national development cannot be overemphasized. Ozigi and Ocho (1981:33-35) had noted that even though the Christian missionaries' major objectives of establishing schools were the propagation of Christianity, their greatest legacy was their educational work and development of indigenous languages into writing. They summarized the contributions of religious education brought by western missionaries as follows:

- Preservation through translation and writing of major Nigerian languages, examples include: Igbo, Yoruba, Efik, Nupe, Hausa, etc., thus creating linguistic homogeneity. For instance, we have 
what is called "The union Ibo" into which the Bible was translated synthesized three major indistinguishable dialects. This became a bond unifying the third largest West African tribe.

- Facilitation of political, social and moral development of the Nigerian people. For example, the Hope Waddell Training Institution (HWTI), Calabar - a Presbyterian Institution, provided early incubation for budding nationalist politicians; many Nigerian statesmen can trace their beginnings to staff-supported school debates there. Frontline Nigerian politicians and nationalists like Dr Nnamdi Azikiwe, first Nigerian president; Sir Francis Akanu Ibiam, HWTI's principal at independence, and the Eastern region's first Nigerian governor; Dr Mbadiwe, federal minister of Communications and Aviation; and Dr Eni Njoku, minister of Mines and Power, and the first indigenous Vice-Chancellor, University of Lagos, etc. were among the people that influenced the shaping of Nigeria nation.

- Creation of law and order in places of inter-tribal wars and anarchy, which ensured the suppression of abominable crimes repugnant to Christian morality. Example: Mary Slessor championed the abolition of killing of twins in the South Eastern part of Nigeria.

- Forestalling insecurity by ensuring safety when travelling without the risk of being harmed or enslaved as was the case in Yorubaland or Iboland before the coming of the missionaries.

- Contribution to social and moral regeneration through churches, schools and health services as well as preventing the demoralization of society. Character training was emphasized along with spiritual development, starting from primary education for converts, who felt that further education would secure them secular work and improve their social standing.

For religious education to thrive as an agent of national development and integration in our contemporary Nigeria, this article recommends the following:

1. To ensure that justice is done in the return of mission schools to their original owners, the law on take-over of such schools should be repealed or amended in line with the new policy of federal government, in order to forestall a future subversion of current 
MoUs with the government on the return of mission schools by an ambitious regime.

2. In order to protect the equal rights of all learners gaining access to education, and to forestall the problem of low enrolments, religious bodies and individuals should appreciate the fact that government alone cannot fund and coordinate education. They should follow the footsteps of early mission schools and not turn education into a commercial venture. 19th century mission schools stood for social integration, provision of literacy, medical care and agriculture to the average person in the society with little or no contribution from the beneficiaries. The adoption of Public Private Partnership (PPP) by the federal government is an indicator that government needs help. Also, the government should not hands-off funding of education, as the action of some state governments suggests today. They should continue to partner with religious bodies and individuals.

3. Every religious education in Nigeria should recognize the rich and diverse religious heritage of the country and should adopt a cooperative model that accepts the rich heritage and the possibility of creative interaction between schools and faith, protecting the youth from religious discrimination or coercion. Learning about religion in these schools should be different from the religious instruction and religious nurture provided by the home, family, and religious community. Religious institutions should explore ways of avoiding or curbing religious fanaticism or extremism. They should aim at creating an integrated and informed community that affirms unity in diversity.

4. Religious education can be extended to the teeming population or adherents of different religions through the adoption of Open and Distance Learning (ODL) option of literacy and empowerment, which may be more flexible and less expensive; the present traditional face to face method of education delivery is very expensive, highly restrictive and discriminatory. 


\section{Conclusion}

This article discussed the divergent views on the Nigerian government takeover and return of mission schools, and the role of religious education (RE) in nation building and integration. Whereas most people argue that the sudden takeover of the schools by the government brought about the collapse of education that was hitherto reputed for high standards in learning and morality, others (especially teachers and parents) argue against the return of the schools to voluntary agencies, citing outrageous school fees, denominational sentiments, tribal prejudices and unhealthy rivalry among citizens, as problems that could militate against national integration and development. By tracing the history of different educational traditions in Nigeria; examining the reasons for the government takeover of mission schools; enumerating and appraising the divergent views on the return of mission schools by government; and suggesting a way forward for religious education in Nigeria, the article concludes that in order to protect the equal rights of all learners gaining access to education, and to forestall the problem of low enrolments, religious bodies and individuals should appreciate the fact that government alone cannot fund and coordinate education. They should take a cue from the 19th century mission schools which bore reasonable costs in providing education to the masses, and should not turn education to a mere commercial venture, but should respect the values they stand to impact through religious education.

\section{Bibliography}

Abdullahi, OE 2012. Secondary Education in Nigeria. Ilorin: University of Ilorin.

Adam, G, Rothgangel, M, Lachmann, R (Eds) 2014. Basics of Religious

Education. Gottingen: Vandenhoeck \& Ruprecht unipress, pp. 15-20.

[Online] www.vr-unipress.de/ [Accessed: 13/11/15]

African Missions 2010. "African Missions, Education and the Road to

Independence: The SUM in Nigeria, the Cameroons, Chad, Sudan and Other African Territories." [Online] http://www.ampltd.co.uk/collections_az/ sum-1/description.aspx [Accessed: 25/1/13] 
Ajidagba, UA 1996. Religious Studies Education. Ilorin: University of Ilorin.

Bassey, MO 1997. "Missionary Rivalry and Educational Expansion in Nigeria, 1885-1945.” [Online] mellenpress.com/mellenpress. cfm?bookid=1633\&pc=9 [Accessed: 13/7/13]

Berman, EH 1974. "African Responses to Christian Mission Education: African Studies Review, Vol. 17, No. 3, pp. 527-540; (...). [Online] http://www.jstor.org/stable/523799 [Accessed: 13/8/13]

Christianity Today 2012. "Fury over mission school fees." [Online] http://www.christianitytoday.com/ct/2012/june/nigeria-fury-over-fees.html [Accessed: 25/1/13]

Efobi, C 2011. "Mission schools returned by state govts in Nigeria." The Church of England Newspaper, December 2, 2011, p 6.

Encyclopedia of Education Research 1969. "Religious Education”. New York: Harper and Row. p1123.

Esu, A. and Junaid, A. 2012. "Nigeria Educational Development:

Traditional and Contemporary." [Online] www.onlinenigeria.com/ education/?blurb=536 [Accessed: 3/6/13]

Fafunwa, AB 1974. History of Nigerian Education. London: George Alien \& Unwin Ltd.

Fagbunmi, M 2005. "Historical Analysis of Educational Policy

Formulation in Nigeria: Implications for Educational Planning and policy". International Journal of African and African American Studies, 4(2):1-7.

Federal Republic of Nigeria 1981. National Policy on Education. Lagos: NERDC Press.

Gatu, J 1971. “Missionary, Go home!” The Church Herald, Nov 5, 1971. Imam, H 2012. "Educational Policy in Nigeria from the Colonial Era to the Post-Independence Period." Italian Journal of Sociology of Education, vol 1. 
Kalu, N 2011. “The return of mission schools". [Online] odili.net/news/ source/2011/aug/16/15.html [Accessed: 8/6/13]

Kalu, OU 1975. “The Peter Pan Syndrome: Aid and Selfhood of the Church in Africa." Missiology 3. Pasadena: American Society of Missiology.

Kalu, OU 1980. The History of Christianity in West Africa. London: Longman.

Mkpa, MA 2013. “Overview of Educational Development: Pre-Colonial to Present Day”. [Online] http://www.Onlinenigeria.com/education/ [Accessed: 27/1/13]

Obibuaku, LO 2005. "Qualitative Education: The Role of Government Take-Over of Schools." [Online] www.nigeriaworld.com/articles/ 2005/sep/061.html [Accessed: 13/7/13]

Onaiyekan, J 2013. "Return of Missionary Schools”. [Online] www.vanguardngr.com/2013/02/return-missionary-schools-to-original-owners-cardinalonaiyekan-tells-govts/ [Accessed: 21/8/13]

Online Nigeria 2013. "Education in Nigeria: A Historical Perspective". [Online] http://www.Onlinenigeria.com/education/ [Accessed: 27/1/13]

Onyekakeyah, L 2013. "Mission schools before and now". [Online] www.in-depthmagazine.com/v2/Indepth_Articles_FEB2013V1_Magazine.htm [Accessed: 14/7/13]

Onyekwere, I 2012. “Orji returns 19 mission schools”. Daily Times Nigeria, September 16, 2012. [Online] www.dailytimes.com.ng/article/orjireturns-19-mission-schools [Accessed: 2/7/13]

Orebanjo, MA 1974. "The relationship between moral and religious Education.” West African Journal of education Xviii (iii), p434.

Osuagwu, U 2012. "The Return of mission schools: The gains, pains”. [Online] economyng.com/news162.html [Accessed: 12/5/13]

Ozigi, A \& Ocho, L 1981. Education in Northern Nigeria. London: George Allen and Unwin Publishers Ltd. 
Taylor, WH (1984). "Missionary Education in Africa Reconsidered: The Presbyterian Educational Impact in Eastern Nigeria 1846-1974." African Affairs, Vol. 83, No. 331, pp. 189-205. London: Oxford University Press.

Taylor, WH (1996). Mission to Educate: A History of the Educational Work of the Scottish Presbyterian Mission in East Nigeria, 1846-196. Leiden: E. J. Brill.

The Guardian Nigeria, 15 January 2013. "Mission Schools Before and Now." [Online] http://www.ngrguardiannews.com/index.php?option= com_content\&view=article\&id=110468:onyekakeyah-mission-schools-before-and-now \&catid=38:columnists\&ltemid=615 [Accessed on 25/1/13]

ThisDay Newspaper, 7 July 2012. "Return of Schools to their owners". [Online] www.thisdayonline.com [Accessed: 13/8/13]

Uka, EM 1989. Missionaries go home? A sociological interpretation of an African response to Christian missions: A study in sociology of knowledge. Bern: Lang.

Uzodinma, E 2013. "Governor Obi donates N733 million to mission schools". [Online] dailypost.com.ng/2013/07/02/governor-obi-donates-n733million-to-mission-schools/ [Accessed: 20/5/2013]

Ward, RRA \& Ariguzo, G 2006. "History of Public-Private Partnerships in Nigerian Universities". [Online] http://ssrn.com/abstract=1494113 [Accessed: 25/1/13] 